\title{
PERANAN KOMUNIKASI TERAPEUTIK OLEH MAHASISWA TINGKAT II JKG TERHADAP SIKAP PASIEN ANAK DALAM TINDAKAN PENCABUTAN GIGI DI KLINIK JKG POLTEKKES KEMENKES RI MEDANTAHUN 2017
}

\author{
Rawati Siregar, Cindy Fortunella Harefa \\ Jurusan Keperawatan Gigi Politeknik Kesehatan Kemenkes RI Medan
}

\begin{abstract}
Abstrak
Komunikasi Terapeutik merupakan proses penyampaian pesan terhadap pasien dalam melakukan perawatan dengan tujuan untuk membina hubungan yang baik antara pasien dan perawat dan menciptakan rasa kerjasama selama proses perawatan gigi yang dilakukan pada pasien anak umur 6-12 tahun di Klinik Jurusan Keperawatan Gigi Poltekkes Kemenkes RI Medan. Penelitian ini bertujuan untuk mengetahui Peranan Komunikasi Terapeutik Oleh Mahasiswa Tingkat II Jurusan Keperawatan Gigi Terhadap Sikap Pasien Anak dalam Tindakan Pencabutan Gigi di Klinik Jurusan Keperawatan Gigi Poltekkes Kemenkes RI Medan. Penelitian yang dilakukan adalah penelitian analitik uji Chi-Square dengan metode survey dan desain Quasi Experiment. Adapun pengambilan sampel dengan purposive sampling, sampel sebanyak 46 dari 342 populasi . Hasil analisa univariat diperoleh data bahwa sampel yang tidak melakukan komunikasi terapeutik, sebanyak 19 sampel (82,7\%) yang tidak kooperatif dan sebanyak 4 sampel $(17,7 \%)$ yang kooperatif. Sedangkan sampel yang melakukan komunikasi terapeutik sebanyak 6 sampel (26\%) yang tidak kooperatif dan sebanyak 74 sampel (74\%) yang kooperatif, Hasil uji chi-square didapatkan nilai $p=0,000$ ( $p<0,05)$ maka Ha diterima dan Ho di tolak yang berarti bahwa ada Peranan Komunikasi Terapeutik Oleh Mahasiswa Tingkat II Jurusan Keperawatan Gigi Terhadap Sikap Pasien Anak. Komunikasi Terapeutik memiliki peranan penting dalam melaksanakan tindakan pencabutan gigi terhadap sikap anak yang kooperatif.
\end{abstract}

\section{PENDAHULUAN}

Kesehatan adalah keadaan sehat, baik secara fisik, mental, spiritual, maupun sosial yang memungkinkan setiap orang untuk hidup produktif secara sosial dan ekonomi (UU No. 36 Tahun 2009). Pembangunan kesehatan bertujuan untuk meningkatkan kesadaran, kemauan dan kemampuan hidup sehat bagi setiap orang agar terwujud derajat kesehatan masyarakat yang optimal (UU Kesehatan No. 23 Tahun 1992).

Tubuh yang sehat tidak terlepas dari memiliki rongga mulut yang sehat. Kesehatan rongga mulut merupakan bagian integral dari kesehatan umum (Pintauli., dkk,). Berdasarkan hasil data dari PUSDATIN Kementerian Kesehatan RI 2014, persentase penduduk yang mempunyai masalah gigi dan mulut dari tahun 2007 sebesar $23 \%$ dan tahun 2013 sebesar $26 \%$.

Komunikasi adalah proses penyampaian gagasan, harapan dan pesan yang disampaikan melalui lambang-lambang tertentu, mengandung arti, dilakukan oleh penyampaian pesan, dan ditujukan pada penerima pesan (Edward Depari). Salah satu komunikasi yang dapat digunakan dalam perawatan Gigi anak adalah komunikas terapeutik bertujuan agar anak menerima perawatan yang akan diterimanya.

Komunikasi Terapeutik adalah proses penyampaian pesan, makna dan pemahaman perawat untuk proses penyampaian pesan, makna, dan pemahaman perawat untuk proses penyembuhan pasien. Komunikasi menjadi penting karena menjadi sarana untuk membina hubungan yang baik antara pasien dengan tenaga kesehatan (Mustikasari, dalam istichomah, A.M,2009).

Komunikasi dalam perawatan disebut dengan komunikasi Terapeutik, dalam hal ini komunikasi yang dilakukan oleh perawat pada saat melakukan Komunikasi Teraupeutik harus mampu memberi dampak dan khasiat Terapi bagi Proses penyembuhan Pasien. Oleh sebab itu, seorang perawat harus mampu meningkatkan pengetahuan dan kemampuan aplikasi Komunikasi Terapeutik agar kebutuhan dan kepuasan pasien dapat terpenuhi (Ode, S. L,2012).I Umumnya, usia 6-12 Tahun adalah masa pergantian Gigi anak, yaitu pergantian gigi susu menjadi gigi dewasa. kadang-kadang ada anak yang terlambat pada masa pergantianya. Selama tidak terjadi masalah, hal itu biasanya dianggap sepele, namun kadang-kadang gigi dewasa muncul pada saat gigi susu belum tanggal. Hal 
inilah yang sangat dikhawatirkan, dan inilah yang disebut dengan Persistensi. Dan inilah akan membuat gigi si anak dapat menjadi berjejal. Untuk itu jika sudah seperti ini bawalah anak yang sudah mengalami hal seperti ini untuk diperiksakan dan memastikan apakah gigi sianak harus dicabut atau tidak.

Berdasarkan Survey awal yang dilakukan di klinik JKG Poltekkes Medan, kurang lebih 50\% anak tidak Koperatif pada waktu dilakukan tindakan pencabutan gigi.

Berdasarkan Uraian diatas, penulis tertarik untuk melakukan penelitian tentang peranan komunikasi terapeutik oleh mahasiswa tingkat II JKG terhadap sikap pasien anak dalam tindakan pencabutan gigi di Klinik JKG Poltekkes Kemenkes RI Medan.

Adapun tujuan penelitian ini adalah untuk mengetahui peranan komunikasi terapeutik oleh mahasiswa tingkat II JKG terhadap sikap pasien anak dalam tindakan pencabutan gigi di Klinik JKG Poltekkes Kemenkes RI Medan tahun 2017. Sedangkan manfaat penelitian ini adalah :

1. Hasil penelitian ini dapat menambah wawasan ilmu pengetahuan dan melatih peneliti mengembangkan pengetahuan berfikir secara objektif dan menjadi bahan untuk penelitian lebih lanjut.

2. Sebagai informasi dan bahan masukan bagi mahasiswa/i jurusan keperawatan gigi dalam memberikan perawatan gigi terhadap anak, Termasuk Dalam Pencabutan Gigi.

3. Meningkatkan keinginan anak untuk menerima perawatan gigi dari perawat gigi.

4. Sebagai sumber data dan informasi bagi peneliti lain yang sejenis.

\section{METODE PENELITIAN}

\section{Jenis dan Desain Penelitian}

Jenis Penelitian yang digunakan pada penelitian ini adalah penelitian Analitik dengan metode survey dan desain penelitian yang digunakan adalah desain atau pendekatan belah lintang (cross-sectional study), dimana penelitian ini bertujuan untuk mengetahui peranan komunikasi terapeutik oleh mahasiswa tingkat II JKG terhadap sikap pasien anak dalam tindakan pencabutan gigi di Klinik JKG Poltekkes Kemenkes RI Medantahun 2017.

\section{Populasi dan Sampel}

Populasi adalah keseluruhan objek penelitian atau seluruh objek yang di teliti oleh peneliti (Soekidjo, 2010). Populasi dalam penelitian ini adalah seluruh mahasiswa JKG Poltekkes Kemenkes RI Medan berjumlah 324 orang. Sedangkan sampel berjumlah 46 orang, diambil secara purposive sampling.

\section{HASIL}

Data yang dikumpulkan adalah hasil penelitian yang dillakukan terhadap mahasiswa/i tingkat II JKG Poltekkes Kemenkes RI Medan. Pengambilan data dilakukan dengan pemberian kuesioner terhadap responden yang tidak melakukan dan yang melakukan komunikasi terapeutik, maka di peroleh data tentang sikap pasien anak. Setelah seluruh data terkumpul, dibuatlah analisa data dengan cara membuat table distribusi frekuensi untuk masing-masing sampel, kemudian dilakukan pengolahan data statistik dengan uji Chi Square

Tabel 4.1 Distribusi Frekuensi Mahasiswa Tingkat II JKG yang melakukan dan yang tidak melakukan komunikasi terapeutik pada pasien anak di JKG Poltekkes Kemenkes RI Medan Tahun 2017

\begin{tabular}{ccc}
\hline Komunikasi Terapeutik & $N$ & Persentase \\
\hline Melakukan & 23 & $50 \%$ \\
Tidak Melakukan & 23 & $50 \%$ \\
\hline \multicolumn{1}{c}{ Total } & 46 & $100 \%$ \\
\hline
\end{tabular}

Dari tabel 4.1 diatas, dapat diketahui bahwa jumlah mahasiswa tingkat II JKG yang melakukan komunikasi terapeutik sebanyak 23 orang $(50,0 \%)$ dan jumlah mahasiswa tingkat II JKG yang tidak melakukan komunikasi terapeutik sebanyak 23 orang $(50,0 \%)$. Jadi, jumlah sampel keseluruhan adalah 46 orang.

Tabel 4.2 Distribusi Frekuensi Sikap Pasien anak dalam tindakan Pencabutan Gigi pada pasien anak di Klinik JKG Poltekkes Kemenkes RI Medan oleh mahasiswa tingkat II JKG yang tidak melakukan Komunikasi Terapeutik Tahun 2017

\begin{tabular}{rrc}
\hline Kategori Sikap & $n$ & Persentase \\
\hline $\begin{array}{l}\text { Tidak Kooperatif } \\
\text { Kooperatif }\end{array}$ & 19 & 82,7 \\
& 4 & 17,3 \\
\hline Total & 23 & 100 \\
\hline
\end{tabular}

Dari tabel 4.2 diatas dapat diketahui bahwa dari 23 mahasiswa tingkat II JKG yang tidak melakukan komunikasi terapeutik, sebanyak 19 orang $(82,7 \%)$ yang tidak kooperatif dan sebanyak 4 orang $(17,7 \%)$ yang kooperatif.

Tabel 4.3 Distribusi frekuensi sikap pasien anak dalam tindakan pencabutan gigi pada pasien anak di Klinik JKG Poltekkes Kemenkes RI Medan oleh mahasiswa tingkat II JKG yang melakukan Komunikasi Terapeutik Tahun 2017

\begin{tabular}{rrc}
\hline Kategori Sikap & $N$ & Persentase \\
\hline $\begin{array}{l}\text { Tidak Kooperatif } \\
\text { Kooperatif }\end{array}$ & 6 & 26 \\
\multicolumn{1}{r}{ Total } & 17 & 74 \\
\hline
\end{tabular}

Dari tabel 4.3 diatas dapat diketahui bahwa dari 23 mahasiswa tingkat II JKG yang melakukan komunikasi terapeutik, sebanyak 6 orang (26\%) yang tidak kooperatif dan sebanyak 17 orang (74\%) yang kooperatif. 
Tabel 4.4 Peranan komunikasi terapeutik oleh mahasiswa tingkat II JKG terhadap sikap pasien anak dalam tindakan pencabutan gigi di Klinik JKG Poltekkes Kemenkes RI Medantahun 2017

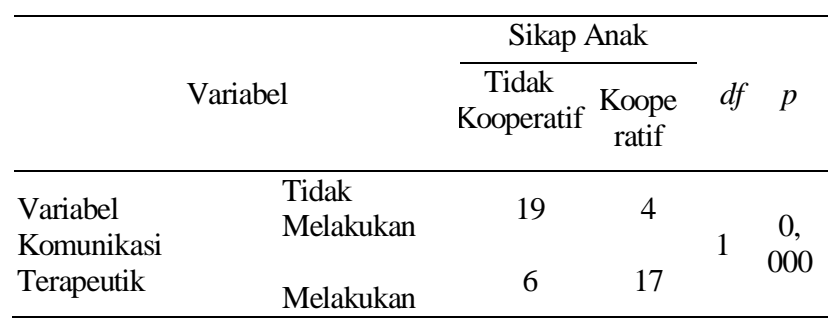

Hasil uji dengan menggunakan uji Chi Square dengan IK 95\% maka didapat nilai $p=0,000 \quad(\mathrm{p}<0,05)$ artinya ada peranan yang signifikan antara komunikasi terapeutik oleh mahasiswa tingkat II JKG terhadap sikap pasien anak dalam tindakan pencabutan gigi di Klinik JKG Poltekkes Kemenkes RI Medantahun 2017

\section{PEMBAHASAN}

Pada penelitian ini, peneliti ingin melihat Peranan Komunikasi Terapeutik Oleh Mahasiswa Tingkat II Jurusan Keperawatan Gigi Terhadap Sikap Pasien Anak dalam Tindakan Pencabutan Gigi. Jumlah sampel pada penelitian ini adalah 46 sampel dari mahasiwa Tingkat II JKG Poltekkes Kemenkes RI Medan Tahun 2017 yang dipilih secara purposive sampling. Hasil analisa univariat tabel 4.2 diperoleh data bahwa dari 23 mahasiswa tingkat II JKG yang tidak melakukan komunikasi terapeutik, sebanyak 19 orang $(82,7 \%)$ yang tidak kooperatif dan sebanyak 4 orang $(17,7 \%)$ yang kooperatif. Hal ini terjadi karena pasien anak merasa takut terhadap tindakan pencabutan gigi yang dilakukan. Komunikasi yang tidak sesuai dengan keinginan pasien anak, membuat pasien anak tersebut menganggap bahwa tindakan pencabutan gigi yang akan dilakukan terhadap dirinya sangat menyakitkan atau akan menyakiti dirinya, sehingga banyak pasien anak yang menangis, takut, berontak bahkan ada yang kabur melihat tindakan yang diberikan oleh perawat gigi di klinik. Peristiwa seperti ini mengakibatkan gagalnya perawat gigi dalam memberikan perawatan berupa tindakan pencabutan gigi pada anak seusia 6-12 tahun tersebut.

Komunikasi Terapeutik adalah proses penyampaian pesan, makna dan pemahaman perawat untuk proses penyembuhan pasien(Istichomah, M 2009). Komunikasi terpeutik befungsi untuk mendorong kerjasama antara perawat dan klien, menganjurkan kerjasama antara perawat dan klien mengatasi persoalan pasien koperatif serta mencegah adanya tindakan negative terhadap pertahanan diri pasien (Ode 2012). Hasil analisa univariat table 4.3 diperoleh bahwa dari 23 mahasiswa tingkat II JKG yang melakukan komunikasi terapeutik, sebanyak 6 orang (26\%) yang tidak kooperatif dan sebanyak 17 orang (74\%) yang kooperatif. Hal ini terjadi Karena perlakuan yang diberikan yaitu komunikasi terapeutik pada saat tindakan pencabutan gigi membuat pasien anak kooperatif dalam menerima tindakan tersebut.
Dari hasil analisa univariat kedua kelompok sampel yang diukur tersebut dapat diketahui bahwa kelompok sampel yang melakukan komunikasi terapeutik dalam tindakan pencabutan gigi, sikap pasien anak lebih kooperatif dari pada kelompok sampel yang tidak melakukan komunikasi terapeutik. Hasil penelitian ini sejalan dengan penelitian Ngudi Waluyo tahun 2011 dengan hasil menunjukkan bahwa ada hubungan komunikasi dengan terapeutik terhadap perilaku anak usia sekolah dalam pencabutan gigi di Puskesmas Ambarawa denga $p$-value sebesar 0,003 .

\section{KESIMPULAN DAN SARAN}

\section{Kesimpulan}

Berdasarkan hasil dan pembahasan pada bab sebelumnya maka dapat disimpulkan :

1. Sikap pasien anak dalam tindakan pencabutan gigi pada pasien anak di Klinik JKG Poltekkes Kemenkes RI Medan oleh mahasiswa tingkat II JKG yang tidak melakukan Komunikasi Terapeutik tahun 2017 diperoleh data bahwa dari 23 mahasiswa tingkat II JKG yang tidak melakukan komunikasi terapeutik, sebanyak 19 orang $(82,7 \%)$ yang tidak kooperatif dan sebanyak 4 orang $(17,7 \%)$ yang kooperatif. Dari data menunjukkan pasien anak tidak kooperatif.

2. Sikap pasien anak dalam tindakan pencabutan gigi pada pasien anak di Klinik JKG Poltekkes Kemenkes RI Medan oleh mahasiswa tingkat II JKG yang tidak melakukan Komunikasi Terapeutik tahun 2017 diperoleh data bahwadari 23 mahasiswa tingkat II JKG yang melakukan komunikasi terapeutik, sebanyak 6 orang (26\%) yang tidak kooperatif dan sebanyak 17 orang (74\%) yang kooperatif. Dari data menunjukan pasien anak kooperatif.

3. Hasil uji dengan menggunakan uji Chi Square dengan IK 95\% maka didapat nilai $p=0,000(\mathrm{p}<0,05)$ artinya ada peranan yang signifikan antara komunikasi terapeutik oleh mahasiswa tingkat II JKG terhadap sikap pasien anak dalam tindakan pencabutan gigi di Klinik JKG Poltekkes Kemenkes RI Medantahun 2017.

\section{Saran}

Diharapkan kepada setiap perawat gigi yang melakukan tindakan pencabutan gigi pada pasien anak, agar menguasai dan memahami penerapan komunikasi terapeutik, karena hal ini dapat membantu dalam mencapai keberhasilan perawatan yang dilakukan.

\section{DAFTAR PUSTAKA}

Dalami, E., dkk. 2009. Buku Saku Komunikasi Keperawatan. Jakarta : Infomedia.

Hidayat, R., dkk. 2016. Perawatan Gigi. Yogyakarta: Andi.

Hutagalung,I. 2015. Teori-teori Komunikasi dalam Pengaruh Psikologi.Jakarta :Indek. 
InfoDATIN. 2014.Situasi Kesehatan Gigi dan Mulut. Jakarta : Pusat Data dan Informasi Kementrian Kesehatan RI

Istichomah,A,m. 2009. Komunikasi Terapeutik Panduan bagi perawat, KDT Yogyakarta

Notomoadjo, S. 2012. Metodologi Kesehatan. Edisi 3. Jakarta : PT. Rineka Cipta

Ode,S.L.2012. Konsep Dasar Keperawatan , Nuha Medika Jakarta
2013. Promosi Kesehatan Teori dan aplikasi. Jakarta : Rineka Cipta

Pintauli, S., dkk. 2016. Menuju Gigi \& Mulut Sehat ; Pencegahan dan Pemeliharaan. Medan : USU Press

Wulandari, D. 2009. Komunikasi dan konseling dalam Praktek Kebidanan, Yogyakarta : Nuha Medika.

Adhy89.blogspot.co.id/2012/12/indikasi-kontraindikasi-pencabutan.html?m=1 